\title{
Finance and Oil
}

\section{Is there a resource curse in financial development?}

\author{
Thorsten Beck ${ }^{1}$
}

First draft: October 2010

\begin{abstract}
This paper shows that the finance and growth relationship does not vary across countries according to the degree of natural resource abundance. This paper also documents less developed financial systems in resource-based economies and banks that are more liquid, better capitalized and more profitable. Firms in resource-based economies use less external finance. Overall, there is some indication of a natural resource curse in financial development.
\end{abstract}

\footnotetext{
${ }^{1}$ Beck (T.Beck@uvt.nl): CentER and European Banking Center,Tilburg University and CEPR. This article is drawn from the author's lecture at a high-level seminar on Natural resources, finance, and development: Confronting Old and New Challenges, organized by the Central Bank of Algeria and the IMF Institute in Algiers, on 4-5 November 2010. Research assistance by Mohamad Hoseini and Radomir Todorov is gratefully acknowledged.
} 


\section{Introduction}

An extensive literature has identified financial sector development as a critical factor in inclusive economic development (Levine, 2005 and Beck, 2009 for overviews). Countries with deeper financial systems grow faster and it is the lowest income quintile that benefits most from this deepening (Beck, Levine and Loayza, 2000; Beck, Demirguc-Kunt and Levine, 2007). Countries with deeper financial systems also experience faster reductions in income inequality and poverty rates. Financial sector development helps industries reliant on external finance grow faster and helps enterprises, especially smaller and more opaque firms overcome financing constraints (Rajan and Zingales, 1998; Beck, Demirguc-Kunt and Maksimovic, 2005).

Most of this work, however, has focused on broad cross-country samples, assuming that the finance-growth relationship is a linear one, constant across countries. ${ }^{2}$ It is more; many papers in the finance and growth literature drop oil countries or natural-resource-based economies in general, arguing that economic development is driven by different factors in these countries and that the financial sector has a different role and structure in these economies.

This paper focuses on financial deepening in resource-based economies. Specifically, we (i) test whether the finance and growth relationship varies across countries depending on the degree to which they rely on natural resources, and (ii) document the development and structure of financial system in natural resource based economies compared to other countries. In the first part, we will use standard finance and growth regressions and allow for a differential relationship of finance in growth depending on the degree to which an economy relies on natural resource exports or is abundant in natural resource wealth. In the second part, we will use aggregate, bank-level and firm-level data to explore whether the depth,

\footnotetext{
${ }^{2}$ There are several papers that have shown non-linear relationships, including Aghion et al. (2005) and Rioja and Valev (2004).
} 
breadth and efficiency of financial systems varies systematically across countries with different degrees of natural resource reliance.

Exploring the role of financial sector development in growth of resource-based economies is interesting and important for both academics and policy makers. There is a large literature on the natural resource curse and the different channels through which resource abundance can influence growth and understanding the role of financial development in this context is critical. Policymakers who care about the development of their countries need to understand the relative importance of different policy areas and the effectiveness of specific policies.

By exploring the role and structure of the financial system in resource-based economies, this paper builds on a large literature that has explored the curse of natural resources (see van der Ploeg, 2010 for a recent survey). The natural resource curse refers to the crowding out of non-resource based activities or investment through price and incentives effects. One form - also referred to as Dutch disease - works through the exchange rate mechanism: commodity exports will put upwards pressure on the real exchange rate, which will turn non-resource exports uncompetitive, ultimately depressing the traded goods sector. The decline of British manufacturing after the discovery of oil in the 1970s and the decline of the Dutch manufacturing sector after the discovery of a natural gas field in 1959 are prominent recent examples. Beyond price effects, the natural resource curse also refers to the distortion of incentives for investment in institutions, education and other public services due to windfall gains from natural resources, as well as negative repercussions for political freedom and stability. It is generally easier to materialize short-term profits from natural resources such as oil than from fixed assets such as manufacturing plants, equipment and machinery, because proceeds from natural resources depend less on the creation of a market, on human capital, and on R\&D investment. This in turn reduces incentives to invest in an 
institutional framework that supports broad domestic market-based exchange, private property rights and the contractual framework supporting non-commodity production (Besley and Persson, 2010). Natural resource wealth also allows less than democratic governments to buy off opposition, avoid accountability and prevent transparency. Natural resources make it more profitable for the elites to hang on to power and block the development of an open society. This, in turn, can foster conflict (Collier and Hoeffler, 2004). In addition, a commodity-induce bonanza can foster a shift from profit-making entrepreneurship towards socially inefficient rent seeking. However, there is also an interaction between institutional development and resource abundance, with countries above a threshold of institutional development able to reap benefits from natural resource wealth.

The empirical literature has provided ample evidence for the natural resource curse and the different channels through which it affects growth. However, this literature has also noted a wide cross-country variation in experiences, with countries like Nigeria having experienced negative growth since its independence, associated with exchange rate effects, rent-seeking and violence stemming from oil exports, while Botswana has experienced positive growth over the past 50 years in spite of being heavily reliant on diamond exports. However, according to Gylfason (2001), only four out of 65 resource-based economies can be considered success stories in terms of growth - Indonesia, Malaysia, Thailand and Botswana - and the three Asian countries still fared less well than their East Asian neighbors Hong Kong, Singapore or South Korea. With few exceptions, however, the literature has not considered the effect of natural resource abundance on financial development or its role in mitigating the natural resource curse (van der Ploeg and Poelhekke, 2007).

In exploring whether there is a natural resource curse in financial development, this paper also builds on a large literature on the determinants of financial deepening across countries. Boyd, Levine and Smith (2001) show the importance of macroeconomic stability 
for financial deepening, while La Porta et al. $(1997,1998)$ and Djankov, McLiesh and Shleifer (2007) show the importance of the contractual and information frameworks for financial development. ${ }^{3}$

Theory and the institutional literature on the natural resource curse provide different hypotheses on the effect of natural resource abundance on financial system development. On the one hand, windfall gains from natural resource abundance and the consequent expansion of the non-traded goods sector can lead to higher demand for financial services, including consumer credit. On the other hand, higher investment in the natural resource sector can lead to lower investment in the financial sector and draw away skills from the financial system. In addition, the heavy dependence of the financial system on a sound institutional framework, including an effective contractual framework, can hamper financial deepening in countries where natural resource abundance undermines institutional development. However, one also has to consider the demand side. There is certainly a lower demand for external financing from the natural resource sector than from non-resource traded goods sector, which will suffer in a Dutch disease scenario. Further, the literature has documented lower savings rates in resource-based economies, which in turn can also explain a lower demand for financial services in resource-based economies.

Theory also makes ambiguous prediction about the finance-growth relationships in resource-based economies. On the one hand, the financial system might be less important as growth depends less on finance-intensive sectors. On the other hand, financial system development might be more important to compensate for the negative effects of Dutch disease and in order to diversify the economy. In addition, financial systems in resourcebased economies can help counter the negative impact of real exchange rate volatility (Aghion et al., 2009).

\footnotetext{
${ }^{3}$ See Beck (2006) for an overview.
} 
This paper is related to a small literature on the institutional resource curse. Beck and Laeven (2006) show that variation in the extent of natural resources across transition economies can partly explain variation in institution building after 1990, when all these countries faced the same challenge of building market-compatible institutions. Cross-country regressions have confirmed this negative relationship between natural resource abundance and the rule of law (Norman, 2009), control of corruption (Papyrakis and Gerlagh, 2004) and overall institutional capacity (Isham et al., 2005).

The remainder of the paper is structured as follows. Section 2 assesses whether the finance and growth relationship varies across countries with the degree of importance of commodities in the economy. Section 3 explores whether commodity-based economies have lower levels of financial development, thus a test of the resource curse for financial system development. Section 4 analyzes banks' balance sheets and income statements to show whether banks are different in resource-based economies. Section 5 uses firm-level survey data to explore difference in firms' use of external finance and firms' financing obstacles across countries with a different reliance on natural resources and aggregate outreach data. Section 6 concludes and provides some policy discussion.

\section{Finance and Growth - is there a natural resource discount?}

This section explores whether the positive relationship between financial development and economic growth varies across countries with the degree of natural resource reliance. In order to do so, we use standard finance and growth regressions, adding a variable capturing natural resource reliance or abundance plus its interaction with financial development. We use two indicators to gauge the reliance of economies on natural resources. The first indicator is Natural Resource Exports, which is the sum of fuel, ores, and metal exports relative to GDP. Data come from World Development Indicators and are available for a 
broad cross-section of countries over the period 1960 to 2008. The second indicator is Subsoil Assets per capita and refers to natural assets (World Bank, 2006). It is computed as the net present value of the income these resources are able to produce, calculated for the year 2000 . Natural Resource Exports ranges from zero in countries like Mauritius to almost $100 \%$ in many oil-exporting countries. Similar Subsoil Assets per capita ranges from zero in countries like Singapore to 80,000 USD in Saudi Arabia. It is important to note that there are important differences between these two measures, with Natural Resource Exports referring to the income stream based on the resources and Subsoil Assets to the actual wealth. ${ }^{4}$

As indicator of financial development, we use a standard indicator from the literature, Private Credit, which is the total claims by financial institutions outstanding on the domestic nonfinancial private sectors, divided by GDP. This indicator ranges from less than $2 \%$ in DRC to almost $150 \%$ in Switzerland. As alternative indicator, we use Liquid Liabilities to GDP, which is defined as currency plus demand and interest-bearing liabilities of banks and nonbank financial intermediaries, divided by GDP, and thus focuses on banks' liability side.

We average GDP per capita growth over the period 1980 to 2007 and run the following regressions:

$$
\begin{aligned}
& g(i)=\alpha_{1}+\beta_{1} \text { Private Credit (i) }+\beta_{2} \text { Private Credit (i) *Natural Resources (i) }+ \\
& +\beta_{3} \text { Natural Resources (i) }+\gamma^{\prime} \mathrm{C}(\mathrm{i})+\varepsilon(\mathrm{i})
\end{aligned}
$$

where $\beta_{1}$ captures the general effect of financial development on growth, while $\beta_{2}$ captures the differential effect in economies that are more resource based.

Following the finance and growth literature, our set of conditioning information includes (i) the log of initial real GDP per capita to control for convergence, (ii) average

\footnotetext{
${ }^{4}$ Brunnschweiler and Bulte (2008) point to important differences in the effect of natural resource dependence and natural resource abundance on institutional and economic development.
} 
years of schooling to control for human capital accumulation, (iii) the share of exports and imports to GDP, (iv) the inflation rate and (v) the ratio of government expenditures to GDP. ${ }^{5}$

The Table 1 results do not show any significant difference in the finance and growth relationship with the degree of natural resource reliance. The column 1 results confirm findings of the cross-country finance and growth literature of a positive relationship between financial development and long-run economic growth, while the column 2 results do not show any differential effect of financial development on growth in resource-based economies as the coefficient on the interaction term enters insignificantly. Columns 3 and 4 confirm our findings using our alternative indicator of natural resource abundance, Subsoil Assets, and our alternative indicator of financial development, Liquid Liabilities, respectively.

Columns 5 and 6 consider the relationship between finance and income inequality. Building on previous work by Beck, Demirguc-Kunt and Levine (2007), we regress the annual growth rate in the Gini coefficient on financial development, Natural Resource Export, their interaction and a set of conditioning information. We find that financial development has a negative relationship with the growth rate in the Gini coefficient, while Natural Resource Reliance has a positive, thus inequality-increasing, impact. The interaction term between the two, on the other hand, does not enter significantly.

Summarizing, this initial evidence does not suggest that the relationship between finance and growth differs across countries with the degree of natural resource abundance, and neither does the relationship between finance and changes in income inequality. These results are certainly not conclusive and more work is needed in this area, especially using industry and firm-level data and disaggregating GDP into the resource-related and nonresource-related component. Preliminary work by Barajas, Chami and Yousefi (2010) shows that there might be a differential effect if one considers panel rather than cross-country

\footnotetext{
${ }^{5}$ Similar sets of conditioning information were used by Beck, Levine and Loayza (2000) and Beck and Levine (2004).
} 
regressions, with financial development having lower if not negative impact on growth in oilexporting countries. But, prima facie, policymakers in resource-based economies should care about financial sector deepening as much as policymakers in other countries.

\section{Finance and Natural Resource - Is there a Resource Curse?}

This section explores whether there is empirical evidence for a resource curse in financial development. Specifically, we assess whether economies more reliant on natural resources have lower levels of financial development after controlling for standard factors associated with cross-country variation in financial development.

Controlling for economic development, countries that rely more on natural resource exports have lower levels of Private Credit Figure 1 presents a partial scatter plot of Private Credit and Natural Resource Exports, controlling for GDP per capita. Here we present data across countries, with data averaged over the period 2000 to 2007 . In the following, we will use multivariate regression analysis to assess the robustness of this finding to controlling for other determinants of financial development.

The literature has pointed to macroeconomic stability and the efficiency of the contractual and information frameworks as important determinants of financial sector development (Boyd, Levine, and Smith, 2001; Djankov, McLiesh and Shleifer, 2007). In our analysis, we therefore control for (i) the log of real GDP per capita, averaged over the sample period (ii) the average inflation rate between 2000 and 2007, (iii) time to enforce a contract in number of days, and (iv) the efficiency of the credit information system, with the latter two measures averaged over the period 2003 to 2007.

In addition to the two financial system indicators introduced above, we focus on several other indicators. The Loan-Deposit Ratio is a measure of intermediation efficiency and is the ratio of total banks' claim outstanding on domestic, non-financial sectors, and total 
bank deposits. Higher ratios indicate higher intermediation efficiency; ratios above one, however, might indicate overheating. We also use two stock market indicators. Specifically, we use Stock Market Capitalization to GDP, a measure of stock market size relative to real economic activity and Stock Market Turnover, which is stock market trading relative to stock market capitalization, which is a measure of the liquidity of the market.

In addition to the financial development indicators defined above, we consider the relationship between natural resource reliance and two indicators of financial structure, i.e. the degree to which a financial system is market or bank-based. Following Beck and Levine (2002), we define Structure-Size as the ratio of Stock Market Capitalization and Bank Assets, where the latter is defined as total banking claims on non-financial (private and public) domestic sectors. Higher ratios would indicate a financial system that is more market-based. Structure-Efficiency is defined as the product of Stock Market Turnover and banks' Net Interest Margin (a negative indicator of bank efficiency). Higher numbers would again indicate a financial system that is more market-based.

Table 2 shows that countries that are more reliant on natural resource exports have lower levels of financial development, even after controlling for other determinants of financial development. The effect is not only statistically, but also economically large. Take the example of column 1. One standard deviation higher Natural Resource Exports imply 10 percentage points lower Private Credit. Consistent with the literature, there is a negative relationship of inflation and contract enforcement inefficiency, while the efficiency of credit information sharing does not enter significantly. Consistently with Figure 1, the log of GDP per capita enters positively and significantly. The column 2 results confirm this finding using subsoil assets, while column 3 confirms the results using Liquid Liabilities. The column 4 results show that lower levels of financial intermediation do not imply lower intermediation efficiency as Natural Resources does not enter significantly in the regression of the aggregate 
Loan-Deposit Ratio. The columns 5 and 6 results show that economies that rely more on natural resources do not have smaller stock exchanges, but significantly less liquid ones. Natural Resource Exports enters insignificantly in the regression of Stock Market Capitalization to GDP, but negatively and significantly in the regression of Stock Market Turnover. The columns 7 and 8 results, finally, show that when measured by size, resourcebased economies have more market-based financial systems, while when measured by efficiency, they have more bank-based financial systems. Given the previous results we can interpret this as suggesting that the market-based nature in terms of size stems from the smaller banking systems in resource-based economies, while the bank-based nature in terms of efficiency stems from the lower stock market liquidity in these countries.

Table 3 explores within-country variation of financial development as function of natural resource reliance. Specifically, here we present estimations with country-fixed effect to explore how Private Credit develops with GDP per capita over time. Here, we focus on a longer sample period, using annual data over the period 1960 to 2007 . We use this sample to assess how the financial system deepens as a function of economic development and other macroeconomic indicators, and whether these relationships vary according to the degree of natural resource reliance.

$$
\begin{aligned}
\operatorname{FD}(i, t) & =\beta_{1} \text { GDP per capita }(i, t)+\beta_{2} \text { GDP per capita }(i, t) * \text { Natural Resource Exports }(i, t)+ \\
& +\beta_{3} \text { Natural Resource Exports }(i, t)+\gamma^{\prime} C(i, t)+\delta^{\prime} X(i)+\varepsilon(i, t)
\end{aligned}
$$

While $\beta_{1}$ thus shows the elasticity of Private Credit to GDP per capita, $\beta_{2}$ indicates whether this elasticity is significantly higher or lower in countries with higher reliance on natural resources. We do not include indicators of the contractual or information framework, as we have limited time-series variation and data availability in these indicators. We include country-specific fixed effects and other time-varying country variables as explained below. 
By including country-specific effects, we effectively explore relationships within countries over time and abstract from the cross-country variation.

The Table 3 indicate that Private Credit increases with GDP per capita, but to a lower extent in countries that rely more on natural resource exports. While the elasticity of Private Credit to GDP per capita is almost one for countries with no Natural Resource Exports, this elasticity is significantly lower in countries with higher Natural Resources. The column 2 results show that the significant interaction between GDP per capita and Natural Resource Exports is not driven by general trade openness. While there is a positive elasticity of Private Credit to the trade share, this elasticity is lower in countries with a higher reliance on natural resources. The column 3 regression, on the other hand, shows that the relationship inverts when using Subsoil Assets, an indicator of natural resource abundance rather than exports. Countries with higher natural resource wealth deepen their financial systems at a faster rate than other countries. This points to an important difference between measures of resource dependence and abundance, as already noted by Brunnschweiler and Bulte (2008) and provides some indication that natural resource abundance can actually be used to the advantage of countries in financial deepening. An important, caveat, however, is that Subsoil Assets is measured in 2000, i.e. includes information that was available at this point in time, not necessarily in 1960 .

The results in columns 4 and 5 show that while real exchange rate appreciation leads to deeper financial systems (though economically very small effect), this relationship is reversed for countries with higher share of Natural Resource Exports. This is maybe the clearest evidence for a Dutch disease effect, i.e. crowding out of non-resource exports through an appreciating exchange rate, can also crowd out financial development.

Summarizing, resource-based economies have smaller banking systems and less liquid stock exchanges than predicted by their level of economic development, degree of monetary 
stability and efficiency of contractual and informational framework. As resource-based economies develop economically, their financial systems deepen at a lower rate than in other countries, though this results holds for natural resource reliance (or dependence) rather than natural resource abundance. These findings are consistent with both a demand-driven and a supply-driven story, i.e. lower demand for financial services resulting in a smaller financial system or supply constraints preventing a financial system from developing. In the next two sections, we therefore focus first on banks' financial statement to assess whether banks in commodity-based economies are different in their business model, efficiency and stability, before turning to firm-level data to assess whether clients are underserved in resource-based economies.

\section{Banks in Resource Based Economies}

While the previous section has provided some evidence for a natural resource curse in financial development, this section digs deeper by exploring banks' business model, efficiency and stability to assess whether there are significant differences across banks in countries with different reliance on natural resources. We use data from Bankscope over the period 2000 to 2007 and construct and compare indicators of business orientation, efficiency, and stability across countries with different degrees of natural resource reliance. We only include banks with at least two observations and countries with data on at least four banks. We restrict our sample to the largest 100 banks in terms of assets within a country so that our sample is not dominated by a specific country. Finally, we eliminate outliers in all variables by winsorizing at the $1^{\text {st }}$ and $99^{\text {th }}$ percentiles.

To compare the business orientation of banks, we use two indicators suggested by Demirguc-Kunt and Huizinga (2010) - the ratio of fee-based to total operating income and the importance of non-deposit funding to total funding - as well as the traditional loan-deposit 
ratio. Further, we use the ratio of liquid assets to total assets. Second, we use three indicators of bank efficiency. Our first efficiency indicator is overhead cost, which is computed as total operating costs divided by total assets. Second, we use the cost-income ratio, which measures overhead costs relative to gross revenues, with higher ratios indicating lower levels of cost efficiency. Third, we use the net interest margin, which is net interest revenue relative to total earning assets. All three indicators decrease in efficiency. To compare the stability of banks across countries, we focus on the z-score, which is defined as the sum of capital-asset ratio and return on assets (ROA), divided by the standard deviation of ROA. It measures the number of standard deviations in ROA that a bank is away from insolvency and thus increases in the stability of banks. We also assess differences across banks and countries in the capital-asset ratio and in ROA, two of the components of the z-score.

We average data over the sample period 2000 to 2007 and run the following regression:

$$
\operatorname{Bank}(i, j)=\alpha B(i, j)+\beta_{1} \text { GDP per capita }(j)+\beta_{2} \operatorname{Natural}(j)+\varepsilon(i, j)
$$

where $\mathrm{i}$ stands for bank and $\mathrm{j}$ for country. B is a set of bank-level control variables, including size (measured in logs of millions of USD of total assets), the share of non-loan earning assets in total assets and fixed assets to total assets. We control for the log of GDP per capita to prevent confounding the relationship between economic development and natural resource dependence. We apply standard errors clustered on the country level, i.e. allow for correlation between error terms of banks within countries, but not across countries to thus control for unobserved factors across banks within a country.

The results in Table 4 show few significant differences across banks according to the reliance on natural resources in the country they operate in. When it comes to business model, we find no significant differences in the share of fee income, the reliance on nondeposit funding or the loan-deposit ratio across countries with different reliance on natural 
resources. We do, however, find that the share of liquid assets in total assets increase as we move from countries with no natural resource exports to resource-based economies. In terms of efficiency, the only dimension where the degree of natural resource reliance seems to matter is the cost-income ratio, which is significantly lower in countries that are more resource-based. On the other hand, there are no significant differences in the net interest margin or overhead costs across countries with different reliance on natural resources. Finally, we find no significant differences in stability of banks across countries with different reliance on natural resources, but find a significant difference in capitalization and profitability. Banks in resource-based economies are significantly better capitalized and more profitable. The higher profitability also explains why we find a lower cost-income ratio for banks in resource-based economies, while there are no significant differences in the other two efficiency indicators. We confirm all our findings using Subsoil Assets as indicator of the resource nature of economies.

Summarizing, the only significant differences between banks in natural-resource based economies and other economies is that banks in the former countries are better capitalized, more liquid and more profitable. There are no significant differences in the business model or in the overall efficiency. As in the aggregate regressions, we find no difference in the intermediation efficiency.

\section{Access to finance in resource-based economies - firm-level evidence}

While the previous sections have focused on aggregate and supplier data to explore differences across countries with different levels of natural resource reliance, we now explore whether these differences also translate into differences in firms' financing patterns and financing obstacles. We rely on the World Bank/IFC Enterprise Surveys, which have been conducted over the past eight years in over 100 countries with a consistent survey 
instrument. ${ }^{6}$ The surveys try to capture business perceptions on the most important obstacles to enterprise operation and growth, but also include detailed information on management and financing arrangements of companies. Sample sizes vary between 250 and 1,500 companies per country and data are collected using either simple random or random stratified sampling. The sample includes formal enterprises of all sizes, different ownership types and across 26 industries in manufacturing, construction, services and transportation.

We focus on several questions that capture firms' financing patterns. First, we compute the share of enterprises with a loan or overdraft facility. Third, we compute the average share of working capital that is financed with external financial source across all enterprises in a country. Finally, we compute the average share of fixed assets that is financed with external financial source across all enterprises in a country. We also focus on a demand-side question, i.e. the share of firms in each country that states that financing is a severe obstacle to its operation and growth.

Figures 2 through 5 show the correlation between Natural Resources and four indicators of firm finance. We see a negative relationship between (i) the share of firms with loans or line of credits, (ii) average share of working capital financed externally, (iii) average share of fixed asset investment financed externally, and the reliance on natural resources. The relationship between the share of firms that rate financing as severe obstacle for the operation and growth of their enterprise, on the other hand, is not significantly correlated with Natural Resources. We note, however, that these negative relationships are, weak, with lots of noise.

The negative relationship between access to external finance and Natural Resources is consistent across firms of all sizes. To assess the relationship between firms' financing patterns and natural resource reliance across different size classes, we recalculate the above

\footnotetext{
${ }^{6}$ See www.enterpriseseurveys.org for more details. Similar surveys were previously conducted under the leadership of the World Bank and other IFIs in Africa (REPD), the Central and Eastern European transition economies (BEEPS) in the 1990s and world-wide in 2000 (World Business Environment Survey).
} 
mentioned indicators within each country for small firms (fewer than 20 employees), midsize companies (20 to 100 employees) and large enterprises (over 100 employees). For each size class, we compare the indicators, averaged across countries with Natural Resource Exports of less than $10 \%$ and averaged across countries with Natural Resource Exports of more than $10 \%$ (Table 5, Panel A). Unlike in the scatter plots, we find significant differences between firms in resource-based economies and other economies across all size groups.

Table 5 Panel B shows some significant difference between firms in resource-based and non-resource based economies in their access to finance. Here, we dig deeper into the loan application process of firms, splitting our sample into countries with Natural Resource Exports, averaged over 2000 to 2009, below $10 \%$ of GDP and above $10 \%$ of GDP. Line 1 shows that firms in resource-based economies are significantly less likely to have a loan, consistent with Figure 2. Among the firms that do not have a loan, however, there is no significant difference in the tendency to apply for a loan (Line 2). Among the firms that decided not to apply, however, significantly more firms in resource-based economies stated that they did not so because of cumbersome application procedures, while a significantly small share of non-applicants stated as reason that they do not need a loan (Lines $3-6$ ). There are no significant differences in other reasons for not applying for a loan. Overall, it seems that the lower use of external finance by firms in resource-based economies is not driven by demand constraints.

Table 6 shows weak evidence for lower bank outreach in resource-based economies and other countries. Here, we follow the model of Table 2 and regress indicators of branch penetration per capita and deposit accounts per capita on (i) log of GDP per capita, (ii) time to enforce a contract, (iii) efficiency of credit information sharing, (iv) inflation and (v) Natural Resource Export or Subsoil Assets. We focus on branch penetration, measured as branches per capita, and account penetration, measured as deposit accounts per capita. Both 
Natural Resource Exports and Subsoil Assets enter negatively in all regressions, but only Natural Resource Exports enters significantly in the regression of Branches per capita. Overall, this seems weak evidence for a lower outreach in resource-based economies.

\section{Conclusions}

This paper tested for the existence of a natural resource curse in financial system development. We can summarize our findings as follows: banking systems are smaller in resource-based economies and stock markets less liquid. Financial deepening is less incomeelastic in resource-based economies, which suggests that resource-based economies invest less in their economies as they grow. In resource-based economies, banks are more liquid, more profitable and better capitalized, but do not have different business models and are not more or less efficient than banks in other countries. Firms in resource-based economies are less likely to have a loan and finance a lower share of working capital and fixed asset investment with external finance; in addition, this gap seems is consistent across firms of all sizes. This is not due to a lack of demand, though. Financial systems in resource-based economies also seem to have lower levels of outreach.

Overall, these findings point to a natural resource curse in financial development, with negative repercussions for resource-based economies. The finance and growth relationship seems as important for resource-based economies as for other economies, so that the underinvestment in the financial sector will have long-term negative repercussions for economic growth. Country characteristics and policies related with financial sector deepening macroeconomic stability, legal system efficiency and an effective information sharing framework - hold as much in resource-based economies as in other economies. It seems that it is a lack of investment. 


\section{References}

To be completed. 
Table 1: Finance and Growth across Countries

\begin{tabular}{|c|c|c|c|c|c|c|}
\hline & (1) & (2) & (3) & (4) & (5) & (6) \\
\hline & $\begin{array}{l}\text { GDP pc } \\
\text { growth }\end{array}$ & $\begin{array}{l}\text { GDP pc } \\
\text { growth }\end{array}$ & $\begin{array}{l}\text { GDP pc } \\
\text { growth }\end{array}$ & $\begin{array}{l}\text { GDP pc } \\
\text { growth }\end{array}$ & $\begin{array}{l}\text { Growth } \\
\text { in Gini }\end{array}$ & $\begin{array}{l}\text { Growth } \\
\text { in Gini }\end{array}$ \\
\hline Initial GDP per capita & $-0.00356 *$ & $-0.00354 *$ & -0.00274 & \multicolumn{2}{|c|}{$-0.00561^{* * *}$} & \\
\hline Private Credit & \multicolumn{3}{|c|}{$0.00798 * * 0.00735^{* * *}$} & $0.0105^{* * *}$ & $*-0.00521 *$ & $=-0.00467 *$ \\
\hline Inflation & 0.00228 & 0.00185 & -0.00067 & 0.00142 & $1.30 \mathrm{E}-05$ & $1.35 \mathrm{E}-05$ \\
\hline Government consumption & $-0.0114 * *$ & $-0.0112 * *$ & $-0.0101 * *$ & $-0.0101^{* *}$ & & \\
\hline Trade & $0.00552^{* *}$ & $0.00545^{* *}$ & * 0.00425 & 0.00203 & -0.00088 & -0.00079 \\
\hline Years of schooling & $0.00222^{* *}$ & ${ }^{*} 0.00227^{* *}$ & * $0.00226^{* *}$ & $0.00308 * *$ & * 0.000685 & 0.000494 \\
\hline Natural Resource Exports & $-0.0360 * *$ & $-0.0284 * *$ & $\Rightarrow-0.0368 * *$ & & $0.0212^{* *}$ & 0.00453 \\
\hline Natural Resource Exports* & -0.00657 & & & & & -0.0108 \\
\hline \multicolumn{7}{|l|}{ Private Credit } \\
\hline Liquid Liabilities & & & $0.0101 * * *$ & & & \\
\hline Natural Resource Exports* & & & -0.00912 & & & \\
\hline \multicolumn{7}{|l|}{ Liquid Liabilities } \\
\hline Subsoil Assets & & & & -0.00064 & & \\
\hline Subsoil Assets & & & & -0.00033 & & \\
\hline \multicolumn{7}{|l|}{ Private Credit } \\
\hline Initial Gini & & & & & $-0.0173^{* *}$ & $*=-0.0173^{* *}$ \\
\hline GDP pc growth & & & & & 0.0464 & 0.0533 \\
\hline Constant & $0.0462^{* *}$ & $0.0450^{* *}$ & $0.0412^{* *}$ & $0.0699 * * *$ & * $0.0578^{* * *}$ & $* 0.0581^{* * *}$ \\
\hline Observations & 104 & 104 & 102 & 102 & 64 & 64 \\
\hline R-squared & 0.421 & 0.419 & 0.411 & 0.381 & 0.322 & 0.329 \\
\hline \multicolumn{7}{|c|}{ Robust standard errors in parentheses } \\
\hline$* * * p<0.01, * * p<0.05, * p<0$ & & & & & & \\
\hline
\end{tabular}


Table 2: Financial development across countries

\begin{tabular}{|c|c|c|c|c|c|c|c|c|}
\hline & (1) & $(2)$ & (3) & (4) & (5) & (6) & $(7)$ & (8) \\
\hline & $\begin{array}{l}\text { Private } \\
\text { Credit }\end{array}$ & $\begin{array}{l}\text { Private } \\
\text { Credit }\end{array}$ & $\begin{array}{l}\text { Liquid } \\
\text { Liabilities }\end{array}$ & $\begin{array}{l}\text { Loan- } \\
\text { deposit } \\
\text { ratio }\end{array}$ & $\begin{array}{l}\text { Stock market } \\
\text { capitalization }\end{array}$ & $\begin{array}{l}\text { Stock } \\
\text { market } \\
\text { turnover }\end{array}$ & $\begin{array}{l}\text { Structure- } \\
\text { Size }\end{array}$ & $\begin{array}{l}\text { Structure- } \\
\text { Efficiency }\end{array}$ \\
\hline Inflation & $-1.750 * * *$ & -0.39 & $-1.976 * * *$ & -0.032 & $0.106 * * *$ & -0.0296 & 0.45 & $0.00762^{* *}$ \\
\hline GDP per capita & $0.181^{* * *}$ & $0.188^{* * *}$ & $0.178 * * *$ & 0.0349 & $0.256 * * *$ & $0.0911^{*}$ & $0.128 * *$ & -0.000205 \\
\hline Time to enforce contract & -0.000178 & -0.000132 & $-6.72 E-05$ & -0.000238 & -0.000201 & -0.00023 & 2.62E-05 & $-1.37 \mathrm{E}-05$ \\
\hline Information sharing & 0.00568 & 0.0197 & $-0.0602 * *$ & $0.0654^{* * *}$ & -0.043 & $0.0452^{*}$ & -0.0226 & $0.00203 *$ \\
\hline Natural Resource Exports & $-0.658 * * *$ & & $-0.733 * * *$ & 0.384 & 0.0148 & $-0.704 * * *$ & $1.557^{* * *}$ & $-0.0251^{* *}$ \\
\hline Subsoil Assets & & $-0.0145^{* *}$ & & & & & & \\
\hline Constant & $-0.672 * * *$ & $-0.866^{* * *}$ & $-0.430 * *$ & $0.610 * * *$ & $-1.303^{* * *}$ & -0.243 & -0.346 & 0.0215 \\
\hline Observations & 142 & 149 & 140 & 152 & 106 & 106 & 102 & 103 \\
\hline R-squared & 0.662 & 0.6 & 0.464 & 0.178 & 0.359 & 0.159 & 0.193 & 0.073 \\
\hline \multicolumn{9}{|c|}{ Robust standard errors in parentheses } \\
\hline$* * * p<0.01, * * p<0.05, * p<0.1$ & & & & & & & & \\
\hline
\end{tabular}


Table 3: Financial development over time

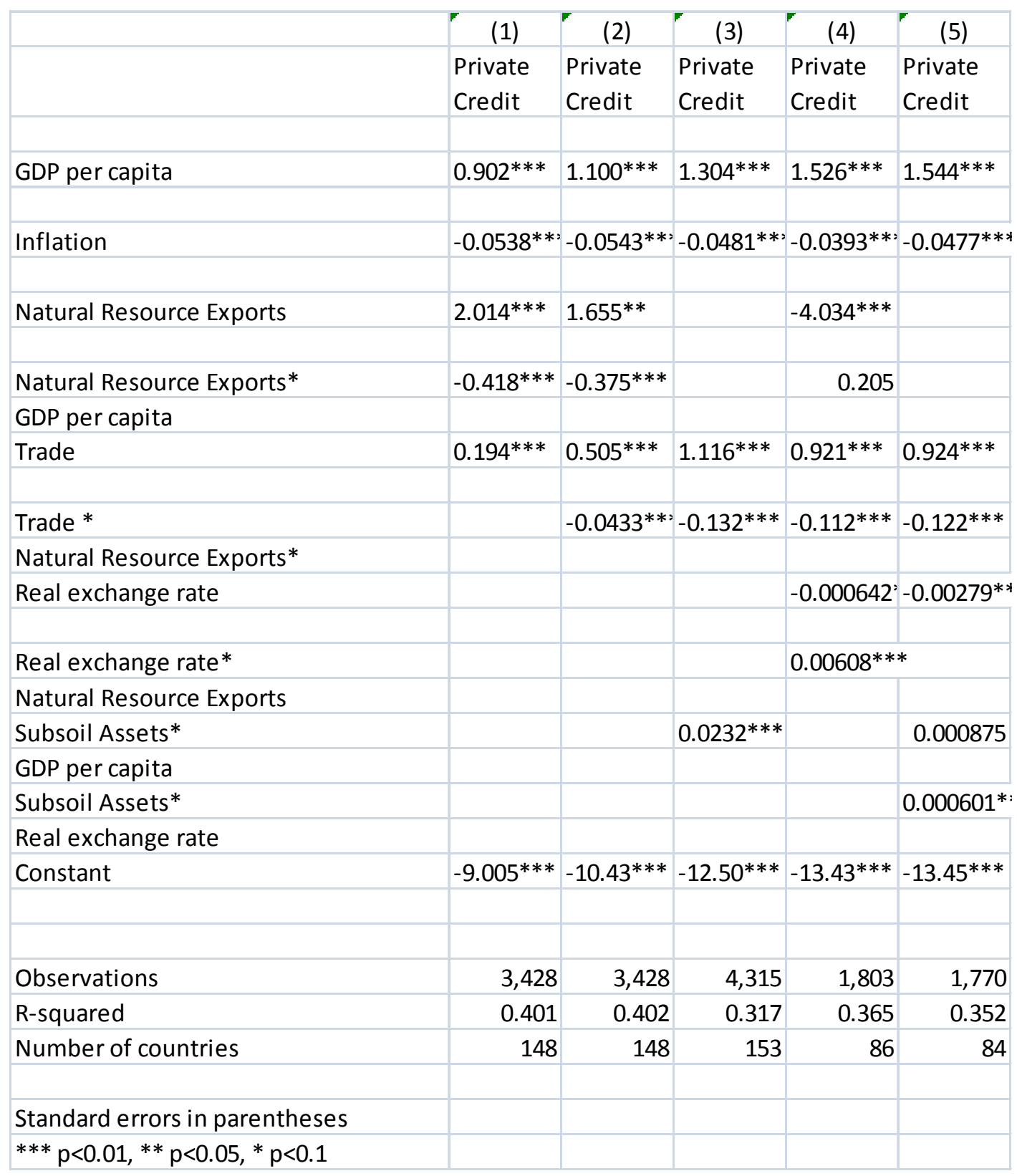


Table 4: Banks' business model, efficiency and stability across countries

\begin{tabular}{|c|c|c|c|c|c|c|c|c|c|c|}
\hline & (1) & (2) & (3) & (4) & (5) & (6) & (7) & (8) & (9) & (10) \\
\hline & $\begin{array}{l}\text { Fee } \\
\text { income }\end{array}$ & $\begin{array}{l}\text { Non } \\
\text { depositf } \\
\text { unding }\end{array}$ & $\begin{array}{l}\text { Loan- } \\
\text { deposit } \\
\text { ratio }\end{array}$ & $\begin{array}{l}\text { Liquid } \\
\text { assets }\end{array}$ & $\begin{array}{l}\text { Cost- } \\
\text { income } \\
\text { ratio }\end{array}$ & $\begin{array}{l}\text { Overhea } \\
\text { d costs }\end{array}$ & $\begin{array}{l}\text { Net } \\
\text { interest } \\
\text { margin }\end{array}$ & Z-score & $\begin{array}{l}\text { Equity- } \\
\text { asset } \\
\text { ratio }\end{array}$ & ROA \\
\hline Fixed Assets & $1.444 * *$ & -0.0316 & $-0.0594 * *$ & -0.257 & $3.549 * * *$ & $0.597^{* * *}$ & $0.00270 * *$ & $-0.563 *$ & $0.277^{* *}$ & -0.0289 \\
\hline Nonloan earning assets & $0.192^{* * *}$ & 0.00139 & $-0.0159 * * 2$ & $0.542^{* * *}$ & 0.0378 & 0.00114 & $-0.000186^{\prime}$ & $-0.0603 * *$ & 0.0108 & 0.000852 \\
\hline Size & -0.375 & $0.555^{* *}$ & $-0.0482 * *=$ & $-1.667 * * *$ & $-1.695 * * *$ & $-0.406 * * *$ & $-0.00284^{*}$ & -0.43 & $-1.988 * * *$ & $-0.0496 * *$ \\
\hline GDP per capita & 0.903 & -0.32 & 0.0245 & -0.0552 & $2.045^{* * *}$ & -0.0176 & $-0.00363^{*}$ & $2.299 * * *$ & $0.462 * *$ & $-0.0988 * * *$ \\
\hline Natural Resource Export & 2.447 & -1.589 & 0.223 & $16.47^{* * *}$ & $-24.73^{* * *}$ & 0.366 & 0.0162 & -1.027 & $6.302 * * *$ & $2.276^{* * *}$ \\
\hline Constant & 19.22 & 0.0671 & $2.094^{* * *}$ & $27.61^{* * *}$ & $60.36 * * *$ & $8.061^{* * *}$ & $0.108^{* * *}$ & $8.565^{* *}$ & $33.40 * * *$ & $2.570 * * *$ \\
\hline Observations & 2,169 & 3,519 & 3,447 & 3,571 & 3,435 & 3,460 & 3,450 & 3,541 & 3,570 & 3,563 \\
\hline R-squared & 0.061 & 0.014 & 0.136 & 0.523 & 0.154 & 0.408 & 0.268 & 0.075 & 0.341 & 0.132 \\
\hline Number of countries & 115 & 116 & 116 & 116 & 116 & 116 & 116 & 116 & 116 & 116 \\
\hline$* * * \mathrm{p}<0.01, * * \mathrm{p}<0.05, * \mathrm{p}$ & $0<0.1$ & & & & & & & & & \\
\hline
\end{tabular}


Table 5: Firms' financing patterns and obstacles across countries

\section{Panel A;}

\begin{tabular}{|c|c|c|c|}
\hline & & Small enterprises & \\
\hline & \multicolumn{3}{|c|}{ Resource Based Econon Non-resource based econon p-value T-stat } \\
\hline External finance in working capital & 23.69719 & 30.73936 & 0.0272 \\
\hline External finance in investment & 28.05876 & 37.48318 & 0.0122 \\
\hline Share of firms with loan & 0.2331552 & 0.3302431 & 0.0059 \\
\hline \multirow[t]{3}{*}{ Share of firms with severe financing obstacles } & 0.1631476 & 0.1683972 & 0.8047 \\
\hline & & Medium-size enterprises & \\
\hline & \multicolumn{3}{|c|}{ Resource Based Econon Non-resource based econon p-value T-stat } \\
\hline External finance in working capital & 30.13262 & 39.5093 & 0.0034 \\
\hline External finance in investment & 30.29018 & 41.90347 & 0.0004 \\
\hline Share of firms with loan & 0.3668703 & 0.4900358 & 0.003 \\
\hline \multirow[t]{3}{*}{ Share of firms with severe financing obstacles } & 0.135517 & 0.1289786 & 0.7031 \\
\hline & & Large enterprises & \\
\hline & \multicolumn{3}{|c|}{ Resource Based Econon Non-resource based econon p-value T-stat } \\
\hline External finance in working capital & 33.04783 & 42.82039 & 0.0095 \\
\hline External finance in investment & 34.82578 & 43.39709 & 0.0216 \\
\hline Share of firms with loan & 0.4958698 & 0.5982997 & 0.0243 \\
\hline Share of firms with severe financing obstacles & 0.1214352 & 0.111606 & 0.6147 \\
\hline
\end{tabular}

\section{Panel B:}

\begin{tabular}{|l|r|r|}
\hline & Resource Based Econon Non-resource based econon $p$-value T-stat \\
\hline Do you have a loan? & 0.308 & 0.421 \\
\hline If you do not have a loan, & & 0.007 \\
\hline did you apply for a loan? & 0.133 & 0.134 \\
\hline & & \\
\hline & & \\
\hline Why did you not apply for a loan & & \\
\hline No need for a loan - establishment has sufficient capital & 0.933 \\
\hline Application procedures for loans or lines of credit are complex & 0.473 & 0.614 \\
\hline Interest rates are not favorable & 0.156 & 0.082 \\
\hline Collateral requirements are too high & 0.143 & 0.130 \\
\hline Did not think it would be approved & 0.069 & 0.000 \\
\hline
\end{tabular}


Table 6: Banking outreach across countries

\begin{tabular}{|c|c|c|c|c|}
\hline & $(1)$ & $(2)$ & (3) & (4) \\
\hline VARIABLES & $\begin{array}{l}\text { Branches } \\
\text { per } \\
\text { capita }\end{array}$ & $\begin{array}{l}\text { Accounts } \\
\text { per } \\
\text { capita }\end{array}$ & $\begin{array}{l}\text { Branches } \\
\text { per } \\
\text { capita }\end{array}$ & $\begin{array}{l}\text { Accounts } \\
\text { per } \\
\text { capita }\end{array}$ \\
\hline Inflation & -0.668 & $-180.6^{* * *}$ & -1.093 & $-128.8^{*}$ \\
\hline GDP per capita & $5.175^{* * *}$ & $546.8^{* * *}$ & $5.387^{* * *}$ & $532.9 * * *$ \\
\hline Time to enforce contract & 0.000966 & -0.243 & 0.000662 & -0.137 \\
\hline Information sharing & 0.0824 & $-130.8^{* *}$ & -0.0671 & $-113.6^{* *}$ \\
\hline Natural Resource Exports & -5.528 & $-1,267^{* *}$ & & \\
\hline Subsoil Assets & & & -0.0532 & -29.82 \\
\hline Constant & $-23.81 * * *$ & $-2,449 * * *$ & $-25.48 * * *$ & $-2,447 * * *$ \\
\hline Observations & 114 & 82 & 114 & 83 \\
\hline R-squared & 0.283 & 0.504 & 0.302 & 0.483 \\
\hline
\end{tabular}


Figure 1: Financial development and natural resources

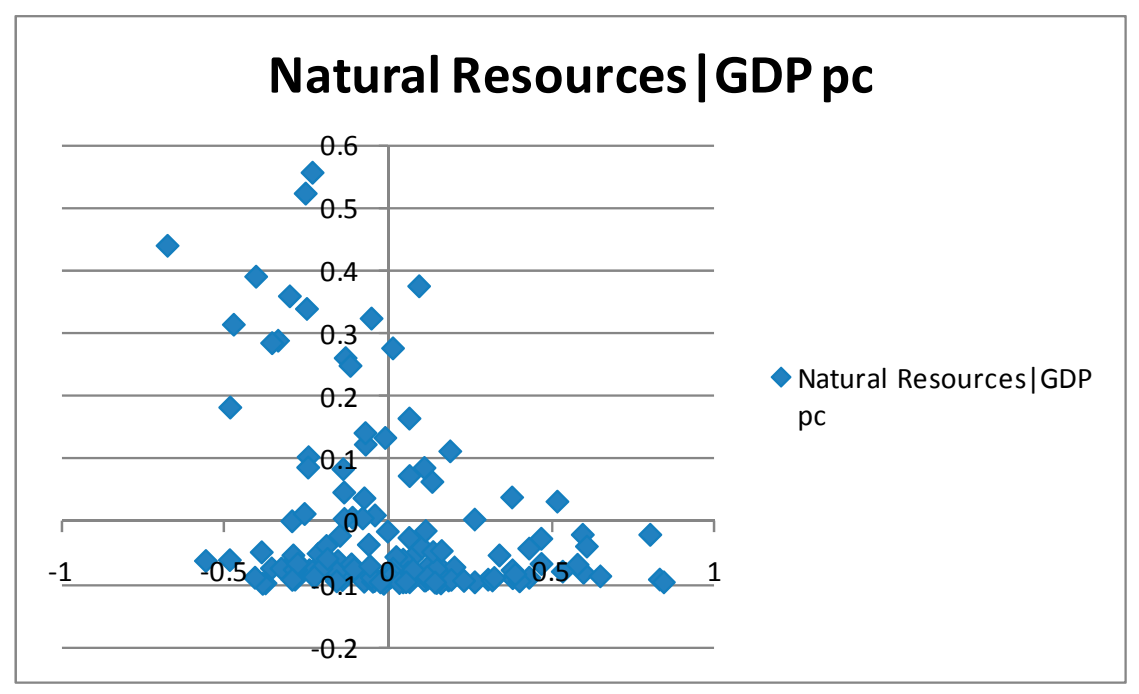

Figure 2: External finance in working capital and natural resource dependence

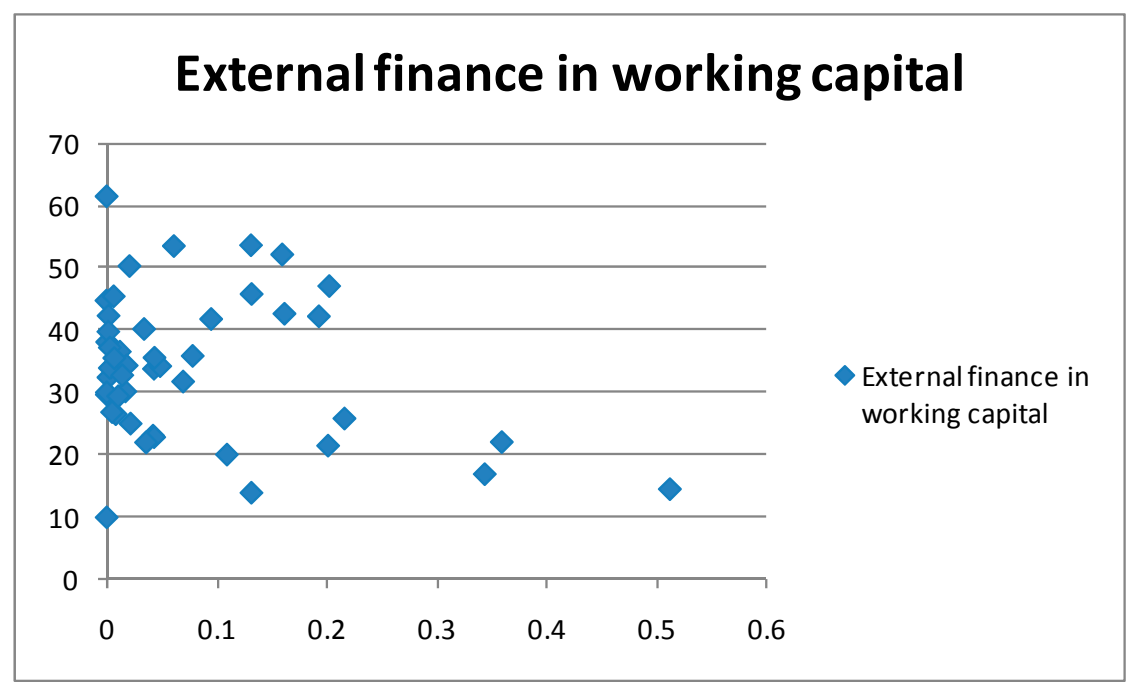


Figure 3: External finance in fixed asset investment and natural resource dependence

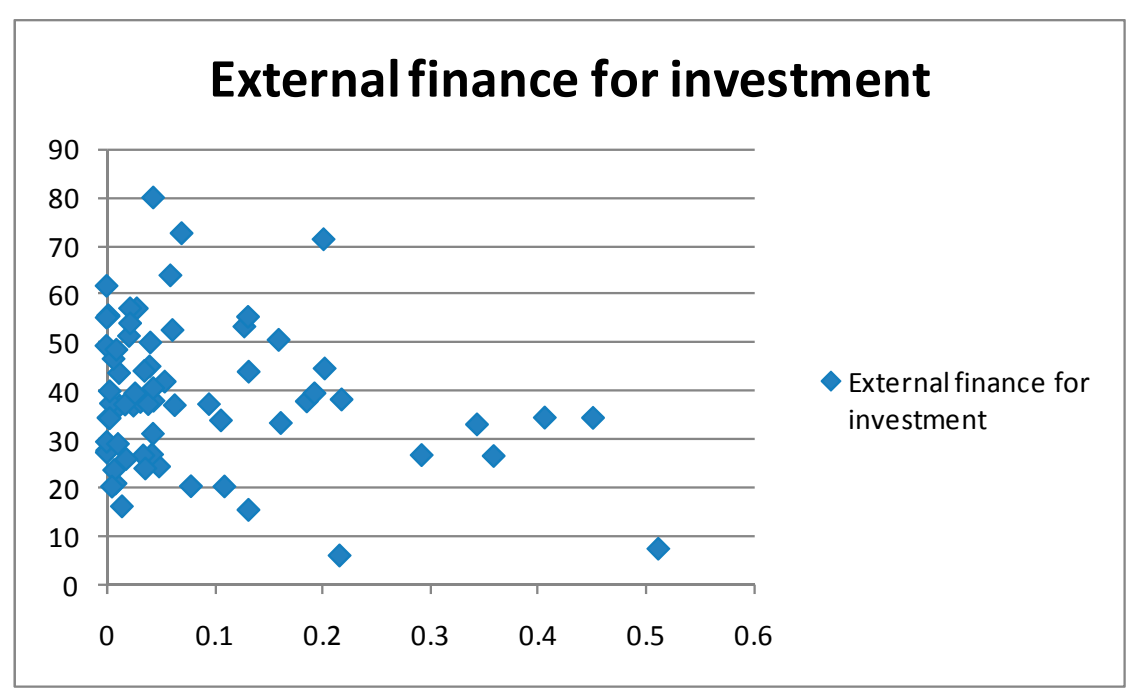

Figure 4: Share of firms with credit and natural resource dependence

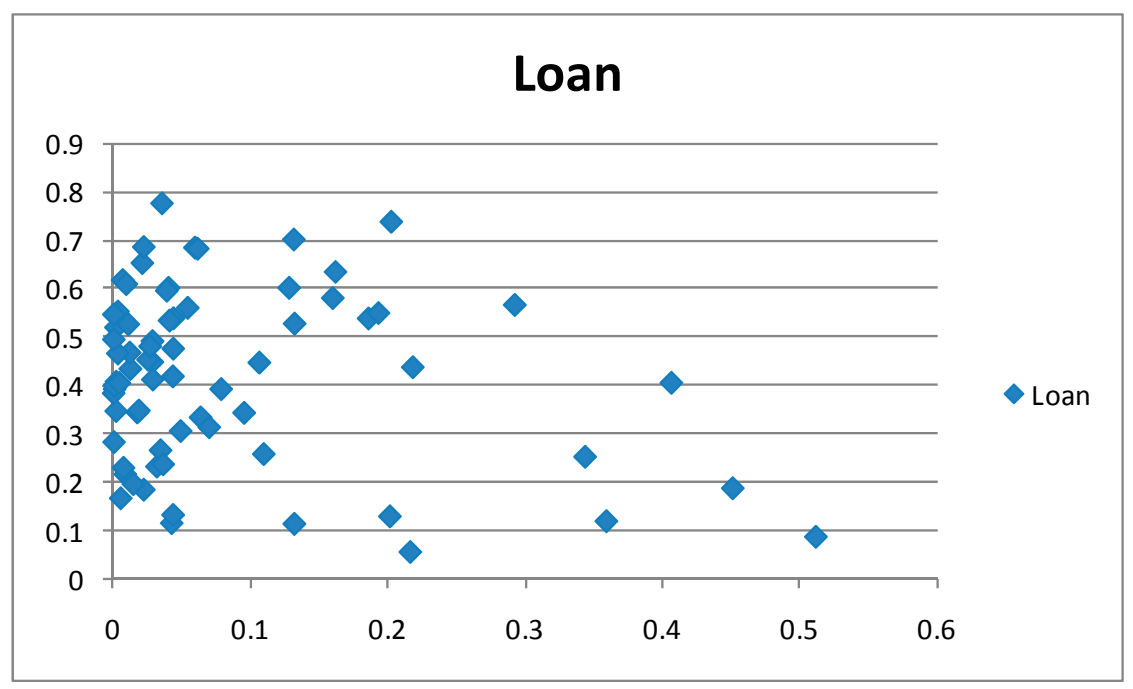


Figure 5: Financing obstacles and natural resource dependence

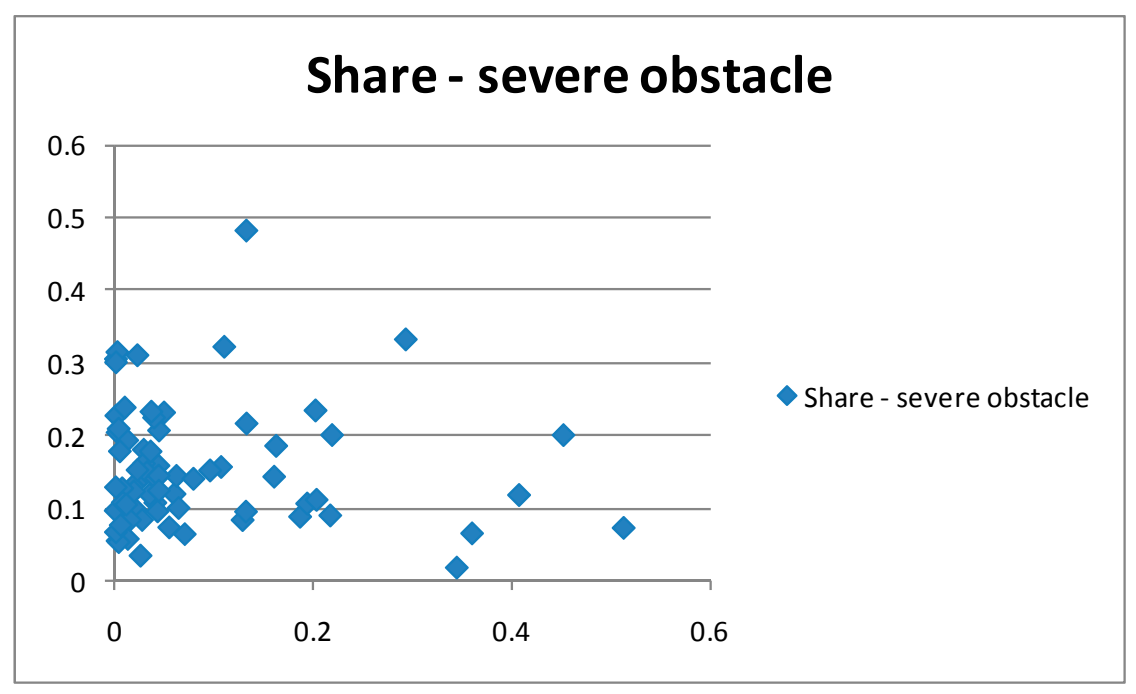

